\title{
HUBUNGAN PARITAS, UMUR DAN USIA KEHAMILAN DENGAN JARAK KUNJUNGAN ANTENATAL CARE TRIMESTER III DI MASA PANDEMI COVID 19 DI PMB BRIDA KITTY DINARUM VWY
}

\author{
Umi Laelatul Qomar' ${ }^{1}$, Lutfia Uli Na'mah'2, Brida Kitty Dinarum Vina Walno Yelvin ${ }^{3}$ \\ ${ }^{1,2}$ STIKES Muhammadiyah Gombong \\ ${ }^{3}$ Bidan Praktik Mandiri \\ *e-mail: ummie.qommar@gmail.com
}

\begin{tabular}{|c|c|}
\hline & Abstract \\
\hline $\begin{array}{l}\text { Keywords: } \\
\text { Paritas, Umur, } \\
\text { Usia kehamilan, } \\
\text { ANC, Covid-19 }\end{array}$ & $\begin{array}{l}\text { Pendahuluan: Bencana non alam yang disebabkan oleh Corona Virus atau } \\
\text { COVID-19 telah berdampak meningkatnya jumlah korban dan kerugian } \\
\text { harta benda, meluasnya cakupan wilayah yang terkena bencana, serta } \\
\text { menimbulkan implikasi pada aspek sosial ekonomi yang luas di Indonesia } \\
\text { Wanita hamil lebih beresiko dalam penularan penyakit menular seperti } \\
\text { Covid-19 baik secara fisilogis maupun psikologis. Pengawasan antenatal } \\
\text { memberikan manfaat dengan ditemukannya berbagai kelainan yang } \\
\text { menyertai kehamilan secara dini, sehingga dapat diperhitungkan dan } \\
\text { dipersiapkan antisipasi yang tepat dalam pertolongan persalinannya } \\
\text { Tujuan: Mengetahui hubungan paritas, umur dan usia kehamilan dengan } \\
\text { jarak kunjungan antenatal care selama pandemi Covid } 19 \\
\text { Metode: merupakan penelitian deskriptif korelatif, dengan pendekatan } \\
\text { cross sectional. Sampel yang digunakan dalam penelitian ini adalah total } \\
\text { sampling pada tempat penelitian selama bulan Mei } 2020 . \text { Uji statistik yang } \\
\text { digunakan pada penelitian ini adalah uji statistik chi square } \\
\text { Hasil: Hasil penelitian menunjukkan dari } 35 \text { responden yang ada bahwa } \\
\text { 65,7\% merupakan primipara, 91,4\% berumur 20-35 tahun, dan 54,3\% } \\
\text { memiliki usia kehamilan } \geq 37 \text { minggu. Kunjungan antenatal care } \\
\text { responden 80\% berjarak } 1 \text { pekan. Analisis bifariat menunjukkan bahwa } \\
\text { tidak terdapat hubungan antara paritas, umur dan usia kehamilan dengan } \\
\text { jarak kunjungan antenatal care selama pandemi Covid } 19 \text { dengan nilai } \alpha \\
>0,05 . \text { Pada variabel paritas nilai alfa } 0,88, \text { variabel umur 0,66 dan pada } \\
\text { variabel usia kehamilan } 0,241 . \text { Kunjungan antenatal care tidak } \\
\text { dipengaruhi oleh paritas, umur dan usia kehamilan. Hal tersebut } \\
\text { dimungkinkan ibu hamil merasa bahwa kesehatan ibu dan janin selama } \\
\text { hamil dianggap penting sehingga tetap melakukan kunjungan sesuai } \\
\text { jadwal. Selain itu kesiapan BPM dalam mencegah penyebaran covid sesuai } \\
\text { dengan protokol kesehatan yang ditetapkan dapat dimungkinkan membuat } \\
\text { responden nyaman dan tidak merasa takut untuk melakukan kunjungan } \\
\text { antenatal care. }\end{array}$ \\
\hline
\end{tabular}

\section{PENDAHULUAN}

Tahun 2019, dunia mengalamai bencana non-alam yang disebabkan oleh Corona Virus. Bencana tersebut telah mengakibatkan dampak secara material dan imaterial. Cakupan wilayah yang terkena telah menimbulkan implikasi pada aspek sosial ekonomi yang luas di Indonesia. 
Pemerintah telah menetapkan bencana non alam ini sebagai bencana nasional melalui Keputusan Presiden Republik Indonesia Nomor 12 Tahun 2020 tentang Penetapan Bencana Nonalam Penyebaran Corona Virus Disease 2019 (COVID-19) sebagai Bencana Nasional. Meskipun pandemi terjadi namun pelayanan kesehatan ibu hamil diselenggarakan dengan mempertimbangkan pencegahan penularan pada ibu hamil dan tenaga kesehatan yang memeriksa ${ }^{1}$. Wanita hamil lebih beresiko dalam penularan penyakit menular seperti Covid-19 baik secara fisilogis maupun psikologis. Resiko tersebut menempatkan wanita hamil pada resiko maternal yang dapat terjadi seperti prematur, hipertensi, preeklamsi, dan keguguran ${ }^{2}$.

$$
\text { Pemeriksaan ANC }
$$

(Antenatal

Care) merupakan pemeriksaan

kehamilan yang bertujuan untuk meningkatkan kesehatan fisik dan mental pada ibu hamil secara optimal, hingga mampu menghadapi masa persalinan, nifas, menghadapi persiapan pemberian ASI secara eksklusif, serta kembalinya kesehatan alat reproduksi dengan wajar ${ }^{3}$. Pelayanan antenatal yang diberikan melalui pengawasan, pemberian pendidikan dan penanganan secara medis untuk mendapatkan kehamilan dan persalinan yang aman ${ }^{4}$. Menurut Pedoman pelayanan antenatal, persalinan, nifas dan bayi baru lahir di era adaptasi kebiasaan baru tahun 2020 kunjungan ibu hamil minimal 6 kali (2 kali pada trimester I, 1 kali pada trimrster II dan 3 kali pada trimester III) ${ }^{1}$. Jadwal kunjungan pemeriksaan kehamilan trimester III yaitu setiap 22 minggu samapai 1 mingg sampai tiba masa kelahiran ${ }^{5}$.

Pengawasan antenatal memberikan manfaat dengan ditemukannya berbagai kelainan yang menyertai kehamilan secara dini, sehingga dapat diperhitungkan dan dipersiapkan antisipasi yang tepat dalam pertolongan persalinannya. Diketahui bahwa janin dalam rahim dan ibunya merupakan satu kesatuan yang saling mempengaruhi, sehingga kesehatan ibu yang optimal akan meningkatkan kesehatan, pertumbuhan, dan perkembangan janin ${ }^{5}$.

Kunjungan antenatalcare dipengaruhi oleh oleh beberapa faktor antara lain mencakup usia, tingkat pengetahuan, status pekerjaan, paritas, jarak kehamilan, pengetahuan ibu dan sikap wanita hamil ${ }^{6}$. Selain faktor tersebut terdapat pula faktor yang memfasilitasi perilaku ibu hamil yang mencakup ketersediaan sarana dan prasarana atau fasilitas kesehatan yang $\mathrm{ada}^{7}$

Pandemi Covid-19 menyebabkan pembatasan pada hampir seluruh Pelayanan masyarakat termasuk di dalamnya pelayanan kesehatan untuk ibu hamil. Resiko penularan Covid yang tinggi membuat wanita hamil takut dalam melakukan pemeriksaan pada kehamilannya. Anjuran dari pemerintah terkait penundaan pemeriksaan dan kelas ibu hamil membuat layanan ibu dan bayi baru lahir terkena dampak baik secara akses maupun kualitas ${ }^{1}$. Pelayanan kesehatan mau tidak mau harus meningkatkan kesiapan layanan dalam upaya pencegahan membuat tenaga kesehatan harus membuat inovasi dan kesiapan yang layak sesuai protokol kesehatan.

\section{METODE PENELITIAN}

Penelitian ini menggunakan design penelitian deskriptif korelatif,dengan pendekatan cross sectional. Sampel yang digunakan dalam penelitian ini adalah total sampling pada tempat penelitian selama bulan Mei 2020. Uji statistik yang digunakan pada penelitian ini adalah uji statistik chi square.

\section{HASIL PENELITIAN}

Hasil penelitian dapat dilihat melalui tabel berikut:

Tabel 1

\begin{tabular}{lcc}
\hline \multicolumn{1}{c}{ Kategori } & Frekwensi & Prosentase (\%) \\
\hline Paritas & & \\
Primigravida & 23 & 65,7 \\
Multigravida & 10 & 28,6 \\
Grandemultipara & 2 & 5,7 \\
Total & $\mathbf{3 5}$ & $\mathbf{1 0 0}$ \\
& &
\end{tabular}




\begin{tabular}{|c|c|c|}
\hline \multicolumn{3}{|l|}{ Umur } \\
\hline $20-35$ & 32 & 91,4 \\
\hline$<20$ atau $>35$ & 3 & 8,6 \\
\hline Total & 35 & 100 \\
\hline \multicolumn{3}{|c|}{ Usia Kehamilan } \\
\hline$<37$ minggu & 16 & 45,7 \\
\hline$\geq 37$ minggu & 19 & 54,3 \\
\hline Total & 35 & 100 \\
\hline \multicolumn{3}{|c|}{ Jarak Kunjungan } \\
\hline 1 pekan & 28 & 80,0 \\
\hline 2 pekan & 5 & 14,3 \\
\hline$>3$ pekan & 2 & 5,7 \\
\hline Total & 35 & 100 \\
\hline
\end{tabular}

Sember: Data Primer 2020

Hasil penelitian menunjukkan dari 35 responden yang ada bahwa $65,7 \%$ merupakan primipara, $91,4 \%$ berumur 20 35 tahun, dan 54,3\% memiliki usia kehamilan $\geq 37$ minggu. Kunjungan antenatal care responden $80 \%$ berjarak 1 pekan

\section{Tabel 2}

\begin{tabular}{|c|c|c|c|c|c|c|}
\hline \multirow{2}{*}{\multicolumn{2}{|c|}{ Kategori }} & \multicolumn{3}{|c|}{$\begin{array}{c}\text { jarak kunjungan } \\
\text { (pekan) }\end{array}$} & \multirow[t]{2}{*}{ Total } & \multirow{2}{*}{$\begin{array}{c}\mathrm{p} \\
\text { value }\end{array}$} \\
\hline & & 1 & 2 & $>3$ & & \\
\hline \multirow[t]{3}{*}{ Paritas } & Primigravida & 18 & 4 & 1 & 23 & \multirow{3}{*}{0,880} \\
\hline & Multigravida & 8 & 1 & 1 & 10 & \\
\hline & $\begin{array}{l}\text { Grande } \\
\text { multipara }\end{array}$ & 2 & 0 & 0 & 2 & \\
\hline \multirow[t]{2}{*}{ Umur } & $20-35$ & 25 & 5 & 2 & 32 & \multirow{2}{*}{0,664} \\
\hline & $<20$ atau $>35$ & 3 & 0 & 0 & 3 & \\
\hline \multirow{2}{*}{$\begin{array}{l}\text { Usia } \\
\text { Kehamilan }\end{array}$} & $<37$ minggu & 11 & 4 & 1 & 16 & \multirow{2}{*}{0,241} \\
\hline & $\geq 37$ minggu & 17 & 1 & 1 & 19 & \\
\hline
\end{tabular}

Sumber: Data Primer 2020

Analisis bivariat menunjukkan bahwa tidak terdapat hubungan antara paritas, umur, dan usia kehamilan dengan jarak kunjungan ANC selama pandemi Covid 19 dengan nilai $\alpha>0,05$. Pada variabel paritas nilai p-value 0,88 , variabel usia $\mathrm{p}$-value 0,66 dan pada variabel umur kehamilan $\mathrm{p}$ value sebesar 0,241

\section{PEMBAHASAN}

Penelitian ini memperlihatkan bahwa pada analisis univariat didapatkan bahwa usia mayoritas partisipan ini merupakan primigravida $(65,7 \%)$. Kehamilan pada primigravida merupakan pengalaman pertama dalam periode kehidupannya sehingga cenderung menyebabkan perubahan yang cukup drastis dalam hal fisik maupun psikologis ${ }^{8}$. Ibu primigravida yang memiliki pengetahuan yang rendah apalagi dalam situasi pandemi maka akan menjadi khawatir terhadap kondisi janin dan dirinya. Selain itu wanita hamil mengalami dilema tambahan mengenai penularan infeksi Covid-19 pada pelayanan kesehatan baik rumah sakit maupun bidan praktik mandiri. Namun, ibu hamil juga membutuhkan pelayanan yang profesional dalam asuhan kehamilan yang didapatkan?

Analisis bivariat menunjukkan bahwa tidak terdapat hubungan antara paritas dengan jarak kunjungan pemeriksaan ANC selama pandemi Covid 19 dengan p-value sebesar 0,880. Hal tersebut memungkinkan responden tetap melaksanakan pemeriksaan kehamilan seperti biasa karena percaya dengan pemberi layanan dalam mengurangi resiko infeksi Covid-19. Kepercayaan terhadap pelayanan kesehatan (baik itu fasilitas dan tenaga kesehatan) sebagai penyedia (provider) pelayanan masyarakat merupakan salah satu faktor ibu hamil dalam pemilihan tempat pemeriksaan ${ }^{10}$.

Tabel 1 memperlihatkan bahwa umur responden $91,4 \%$ merupakan usia reproduksi sehat. Sisanya merupakan kelompok yang beresiko dalam kehamilannya. Kehamilan yang beresiko dapat kendalikan dengan asuhan kehamilan yang tepat. Pemeriksaan antenatal care medeteksi secara dini adanya resiko pada kehamilan sehingga memudahkan pemberi layanan dalam perencanaan asuhan pada kehamilan dan persalinan sesuai dengan tingkatan resiko yang dialami. Hasil uji statistik didapatkan nilai p-value 0,664 yang menunjukkan bahwa tidak terdapat hubungan antara umur responden dan jarak pemeriksaan ANC. Usia seseorang dapat mempengaruhi pola pikir orang tersebut. Usia 20-35 tahun yang dikatakan sebagai usia produktif sehat membuat wanita hamil 
dapat berfikir lebih rasional dibandingkan dengan usia yang digolongkan sebagai faktor resiko ${ }^{7}$. Karena lebih berfikir rasional dimungkinkan ibu hamil lebih memiliki semangat dan motivasi dalam pemeriksaan kehamilan dan mengurangi ketakutan terhadap adanya resiko terpapar infeksi Covid-19.

Responden penelitian ini 54,3\% memiliki usia kehamilan $\geq 37$ minggu. Pada trimester III wanita hamil bersiap untuk proses kelahiran yang akan terjadi. Dengan mayoritas responden adalah primigravida dimungkinkan keingintahuan mengenai kondisi janin dan ibu lebih tinggi. Wanita hamil pada kondisi pandemi dilema untuk bersalin di rumah sakit ${ }^{10}$. Hal tersebut memungkinkan wanita hamil lebih memilih untuk melahirkan di bidan praktik mandiri dibandingkan RS yang merawat pasien covid-19. Kesiapan tempat pelayanan kesehatan atau BPM dalam melakukan pencegahan penularan sesuai dengan protokol kesehatan membuat pasien lebih nyaman dalam melakukan pemeriksaan kehamilan.

\section{SIMPULAN DAN SARAN}

Penelitian ini menyimpulkan bahwa $65,7 \%$ merupakan primipara, 91,4\% berumur 20-35 tahun, dan 54,3\% memiliki usia kehamilan $\geq 37$ minggu. Kunjungan antenatal care responden $80 \%$ berjarak 1 pekan. Kunjungan ANC selama pandemi Covid 19. Tidak dipengaruhi oleh paritas, umur dan usia kehamilan. Diharapkan pemberi layanan kesehatan dapat meningkatkan upaya pencegahan penularan Covid-19 sehingga memberika rasa aman dan nyaman pada ibu hami selama kehamilan, persalinan maupun nifas. Peneliti selanjutnya dapat mengembangkan penelitian ini, dengan melakukan penelitian variabel lain yang dapat mempengaruhi kunjungan antenatal care pada semua trimester kehamilan.

\section{DAFTAR PUSTAKA}

[1] Kemenkes RI. (2020). Pedoman Pelayanan Antenatal, Persalinan, Nifas dan Bayi Baru Lahir di Era Adaptasi Kebiasaan Baru. Jakarta: Kementrian Kesehatan RI.

[2] Durankuş F, Aksu E. . (2020). Effects of the COVID-19 pandemic on anxiety and depressive symptoms in pregnant women: a preliminary study. Matern Fetal Neonatal Med May, 1-7.

[3] Kemenkes. (2018). Pentingnya Pemeriksaan Kehamilan (ANC) di Fasilitas Kesehatan. Jakarta.

[4] Mufdlilah. (2009). ANC Fokus, Antenatal Care Focused. Yogyakarta: Nuha Medika.

[5] Manuaba, Ida Ayu Chandranita dkk. (2010). Ilmu Kebidanan, Penyakit Kandungan, dan KB Untuk Pendidikan Bidan, Ed.2, . Jakarta: EGC.

[6] Notoatmodjo S. (2012). Promosi kesehatan dan perilaku kesehatan. Jakarta: Rineka Cipta; 2012. Jakarta: Rineka Cipta.

[7] Agus Y \& Horiuchi S. (2012). Factors influencing the use of antenatal care in. Bio Medical Central Pregnancy and Chilbirth.

[9] Ho PL, Tang XP, Seto WH. (2003). SARS: hospital infection control and admission strategies. Respirology, S41-S4.

[8] Bethsaida Janiwarty \& Herri Zan Pieter. (2013). Pendidikan Psikologi untuk Bidan Suatu Teori dan Terapannya. Yogyakarta: Andi Offset.

[10] Syarifah Nuraini dan Aan Kurniawan. (2015). Dinamika Pemilihan Pemeriksaan Kehamilan Dan Persalinan Di Puskesmas Kassi-Kassi, Kota Makassar, Sulawesi Selatan. Buletin Penelitian Sistem Kesehatan Vol. 18 No. 2, 131-139. 